\title{
Plastic surgery and Greek mythology
}

\author{
Achilleas Thoma MD FRCSC FACS \\ Division of Plastic and Reconstructive Surgery, Department of Surgery, St Joseph's Hospital, McMaster \\ University, Hamilton, Ontario
}

\begin{abstract}
"Nothing good and beautiful can be achieved without sacrifice" - Prometheus
\end{abstract}

$\mathrm{G}$ reek mythology is a collection of the legends of the ancient Greeks which starts with the creation of the universe from chaos and covers the five ages of man. The ancient Greeks believed that the gods created the human race not only once, but five times. They were the golden, silver, bronze, heroic and iron generations (1).

It was during the heroic generation that most of the famous heroes of the ancient Greeks such as Heracles (Hercules), Jason (of the Argonauts) and Achilles came to the world. It is this particular period with which Greek mythology is most involved.

These stories came from various sources such as ancient artworks, ruins of temples unearthed by archeologists and the pottery and sculpture that fills the national museums of many countries. Although there are variations on the Greek myths, the generally accepted versions are those found in Homer's 'Iliad' and 'Odyssey'. Scholars believe that Homer lived somewhere between $750 \mathrm{BC}$ and $1000 \mathrm{BC}$. These two epics are widely considered to be the beginning of the European literature (1). Other sources include Hesiod, a writer of legends and myths who lived somewhere between 800 and $700 \mathrm{BC}$, and Apollonius of Rhodes who followed Hesiod by 400 years. Unfortunately, the works of Apollonius were lost in the fires of the famous libraries at Pergamon and Alexandria. His works were referred to by the Roman poets Virgil and Ovid.

Another important source of Greek mythology is the Greek theatre, in particular the surviving works of the famous playwrights Aeschylus (525 BC to $456 \mathrm{BC}$ ), Sophocles (496 BC to $406 \mathrm{BC}$ ) and Euripides (485 BC to $406 \mathrm{BC}$ ) (2).

This paper was presented in part at the 48th Annual Meeting of the Canadian Society of Plastic and Reconstructive Surgeons, Ottawa, May 28, 1994.

Correspondence and reprints: Dr A Thoma, Division of Plastic and Reconstructive Surgery, Department of Surgery, St Joseph's Hospital, 208-220 James Street South, Hamilton, Ontario L8P 3A9. Telephone (905) 523-0019, Fax (905) 523-0229

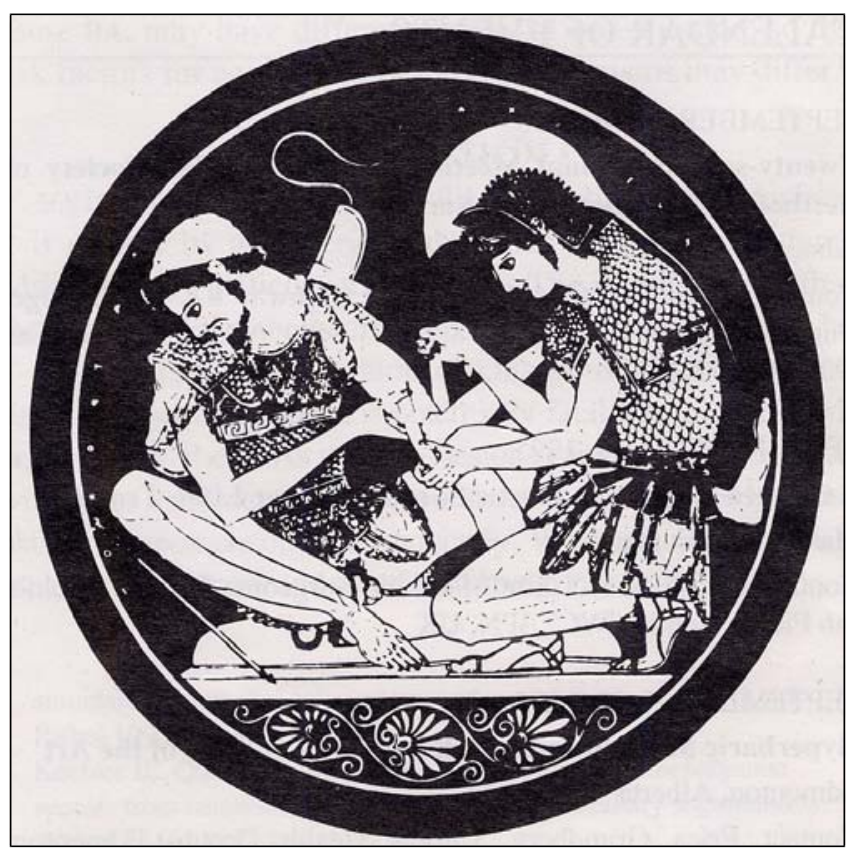

Figure 1) Achilles bandaging the injured arm of his best friend Patroclus

Greek mythology tells us about the interaction between gods and humans, heroes and monsters. In contrast to the myths of other cultures, Greek mythology survived for over three millennia because the Greek gods had human traits with which mortals could identify. The Greeks imagined their gods to be flawed just like themselves.

When one reads the Greek mythology, one is intrigued by the similarities between it and the Christian mythology born 1000 years later. For example, the myth of Prometheus chained on the rocks and tortured by an eagle eating his liver which continued to regenerate and prolong his pain for stealing the fire from Mount Olympus to save mankind is reminiscent of Jesus' crucifixion. This should not be surprising, however, as the advent of Christianity occurred in the Hellenistic world where the Greek language, culture and myths were paramount. 
Although most scholars accept the Homeric version of the Greek myths as official, many people in the Mediterranean basin have their own versions. An example of this was found at the Olympic games of Barcelona in Spain in 1992. During the opening ceremonies there was a huge effigy of Heracles (Hercules) entering the Olympic stadium. The people of Barcelona believe that it was Heracles who built their city. In the Homeric version, there is no such mention of this event. It is probable that Barcelona was built during Heracles' expedition to accomplish his tenth labour which took him beyond Gibraltar (pillars of Heracles) onto the Atlantic ocean to fetch Geryon's cattle (3).

The ancient Greeks believed in the 12 Olympian gods. This introduced the concept of specialization. They did not believe that one god could be omnipotent and therefore they identified their gods with particular tasks, ie, Poseidon, god of the seas, Ares, god of war, Athena, goddess of wisdom, Aphrodite, goddess of love, etc. In reviewing the Greek mythology, one can find references relevant to the specialty of plastic surgery.

\section{WOUND HEALING AND SCARS}

The scene depicted in Figure 1 is taken from a kylix (drinking vessel) dated around $490 \mathrm{BC}$ and housed in the Antiquity Museum of Berlin $(4,5,6)$. It shows Achilles, one of the heroes of the Trojan war, bandaging the arm of his close friend Patroclus with a two-tailed bandage. This is perhaps the oldest pictorial representation of bandaging and wound management, since the event it depicts took place about 1000 BC.

At one stage of the Trojan war, Achilles had a feud with Agamemnon, the commander-in-chief, over a beautiful girl named Chryseis who had been given to Achilles as a prize of the war. Agamemnon took her for himself, pulling rank as the commander-in-chief. Achilles, the bravest warrior in the Greek camp, refused to fight and as a result the Trojans managed to take the upper hand. Achilles' friend Patroclus, in despair to push back the Trojans, picked up Achilles' armour and fought valiantly but was killed by Hector in battle.

While there is no mention of an arm injury suffered by Patroclus in the Iliad (4), we learn from another source (7) that it took place in Mysia, where the Greeks mistakenly landed initially on their way to Troy. Achilles was leader of the first expedition, but his mother, Thetis, knew that her son would die in the war with Troy because of his vulnerable heel and falsified the navigation plans such that the Greeks landed in Mysia instead. It was here that Patroclus was involved in a skirmish with Telephus (son of Heracles). The wound depicted on the Kylix most likely represents the injury that occurred in this location.

Telephus was also injured on the leg in the same skirmish by Achilles. His wound would not heal, most likely due to osteomyelitis. The oracle had told him that "only he who wounded you can cure you". Telephus went to Mycenae where the Greek force had reassembled. He met Achilles and begged him to cure his leg. While Achilles had knowledge of medicine and surgery, taught to him by the famous centaur
Cheiron, he refused to treat his enemy. The cunning Odysseus (Ulysses) took Achilles' spear which had wounded Telephus and scraped some rust into the wound which caused it to heal immediately! Out of gratitude, Telephus led the Greek army the correct way to Troy this time. Thus, Telephus, married to Priam's daughter (Priam was king of Troy), betrayed his father-in-law in order to save his leg.

Another famous wound in Greek mythology was a snake bite suffered by Philoctetes, another hero of the Greek army which conquered Troy. This particular event occurred on the island of Lemnos just offshore from Troy. The Greeks left him behind on the island since in his condition he was of no use to them in the war.

The war was not going well for the Greeks, and the oracle told them that Troy could not be taken without Heracles' arrows which were safeguarded by Philoctetes. Odysseus brought Philoctetes to Troy and there in the Greek camp he was successfully treated by Machaon, the son of Asclepius, and proceeded to fight in the war $(5,7)$.

A famous scar in Greek mythology was the one on the leg of Odysseus. After the fall of Troy, Odysseus spent 10 years roaming the seas before managing to reach Ithaca. He disguised himself as a beggar to enter his palace in an attempt to get rid of the suitors who had intentions on his wife, Penelope. His old wet nurse Eurycleia recognized her old master by the scar on the leg while washing his feet. Odysseus begged her not to reveal his identity until he got rid of his enemies (8).

\section{HAND SURGERY}

The first reference to hand surgery is also found in Greek mythology. During the battle of the Titans, Mother Earth was so enraged at Zeus for being harsh on her children after his victory over Cronus, that she gave birth to a monster Typhoon and sent him against Zeus. This monster had 100 heads and fire flashed from his eyes. With its snaky coils, Typhoon avulsed the tendons from Zeus' hands and feet. Unable to fight, Zeus was captured and imprisoned in a cave by the monster.

Hermes (Mercury), the God of Commerce and messenger to the Olympian gods, came to the rescue of Zeus. He stole back Zeus' tendons from Typhoon and sutured them back into his feet and hands. With his tendons back, Zeus was able to fight again and defeated the monster (9).

Various hand injuries were described in the Iliad and their initial management included cleansing with warm water. In one particular episode, Hector hit Teucer with a ragged stone fracturing his clavicle and paralyzing his hand, describing the first brachial plexus injury (10).

\section{RECONSTRUCTIVE SURGERY}

In terms of reconstruction, there is the story of Tantalus, who was King of Phrygia and was also son of Zeus. He was one of the few mortals invited to Mount Olympus, home of the gods. After a while, he started thinking of himself as a god and his excessive pride led to his downfall. He thought he was immune from any punishment after he got away with 
some minor infractions. He felt he was as powerful as Zeus and decided to commit a most heinous crime, killing his own son and serving him at a banquet to the Olympian gods.

Zeus hurled Tantalus to Hades to suffer eternal torture. He condemned him to stand in a pool of crystal clear water. When he was afflicted by thirst and bent down to drink, the water disappeared. Above his head were branches bearing fruit, but when he reached to take one, the branches lifted higher. His punishment was eternal hunger and thirst. Zeus ordered Hermes to collect all the pieces of Tantalus' son from the dinner table and reconstruct them together. The shoulder part was missing, however. Absentminded goddess Demeter, who was preoccupied with her daughter Persephone's disappearance, had eaten that part. Hephaestus (the blacksmith god) reconstructed the shoulder with ivory and then Zeus breathed life into Tantalus' son, Pelops. Legend has it that anyone who has a birthmark on the shoulder is a descendent of Pelops.

\section{CRANIOFACIAL DEFORMITIES AND SURGERY}

The first reference to craniofacial abnormalities comes to us from the Odyssey. The Cyclopes were huge monsters with single eyes in the middle of their foreheads. Although this severe deformity is incompatible with life, the Greek mythology portrayed the monsters with immense strength. One such Cyclops was Polyphemus who captured Odysseus in his attempt to sail back to his homeland, Ithaca. The cunning Odysseus gave Polyphemus wine to drink and then blinded the intoxicated Cyclops by driving a hot red stake through his singular eye, facilitating his escape (8).

A more intriguing reference to craniofacial surgery is the birth of goddess Athena. Zeus had been afflicted by terrible headaches, and in a desperate attempt to relieve his headache, ordered his son Hephaestus to split his head open from which sprang the goddess of wisdom Athena (1).

\section{REFERENCES}

1. Graves R. Greek Myths. London: Cassell \& Co Ltd, 1955.

2. Morford MPO, Lenardon RJ. Classical Mythology, 4th edn. New York: Longman, 1991.

3. Stephanides M. Heracles: Greek Mythology. Athens: Sigma Publications, 1989.

4. Mueller B. Achilles bandaging Patroclus. Surgery 1989;106:589.

5. Balas P. Ancient Hellenic surgery. Bull Am Coll Surg 1994;79(6):22-9.

6. Singer C. Greek Biology and Greek Medicine. London: Oxford University Press, 1922.

\section{FETAL SURGERY}

From the Bacchae by Eurypides we learn that Zeus performed the first fetal surgery (11). The goddess Hera, wife of Zeus, was bitterly jealous of the lovely Semele with whom Zeus had had an affair. She disguised herself as an old lady and told Semele that Zeus was an imposter claiming to be a god, whereas in fact he was just a mortal. Semele started doubting Zeus and made him give his oath that he would do whatever she asked him do. Her wish was for Zeus to appear in front of her in all his glory as a god. Zeus had no choice but to comply since he gave his oath to the holy river Styx. The tremendous heat which radiated from this metamorphosis burned poor Semele into cinders. Just before her death, Zeus retrieved the fetus from Semele's uterus and transplanted it into his own thigh. Seven months later, god Apollo was born.

\section{OUTRAGEOUS FEES}

The subject of fees that physicians should or should not charge can be found in the story of Melampus, who was considered to be a wise seer and healer (12). He acquired his healing powers in a strange way. One day he saw an eagle swoop down on a snake nest and ran to the rescue. Unable to save the parent snakes, Melampus saved the little ones from the eagle's talons. In gratitude, the little snakes came to him in his sleep and licked his ears clean, bestowing on Melampus the ability to comprehend the speech of wild animals and birds and giving him an incredible healing power. His fame grew in the ancient world, but along with his fame so did his fees. When he was asked to cure King Proteus' daughter who went mad, he asked for one third of the kingdom. When his other daughter suffered a similar illness, his fee was two thirds of the kingdom. Normally such greed would have been punished by the Olympian gods; however there is no evidence that this occurred. It seems that Melampus got away with it.

\footnotetext{
7. Stephanides M. The Iliad - The Trojan War. Athens: Sigma Publications, 1989.

8. Homer. The Odyssey. Rieu EV (trans). Penguin Books, 1946.

9. Stephanides M. The Battle of the Titans. Athens: Sigma Publications, 1989.

10. Homer. The Iliad. Rieu EV (trans). Penguin Books, 1950.

11. Sandys JE. The Bacchae of Euripides, 4th edn. Cambridge: University Press, 1900.

12. Stephanides M. Theseus-Perseus. Athens: Sigma Publications, 1989.
} 